\title{
ANALISIS FAKTOR-FAKTOR YANG MEMPENGARUHI KEPUASAN MAHASISWA TERHADAP PELAYANAN UPBJJ-UT MEDAN
}

\author{
Asnah Said ${ }^{1}$, Sondang Purnamasari Pakpahan ${ }^{2}$, dan Hernawaty Damanik ${ }^{3}$ \\ Universitas Terbuka Jl Cabe Raya Pondok Cabe Pamulang Tangerang Selatan ${ }^{1}$ \\ Universitas Terbuka UPBJJ Medan Jl Bromo No.29 Medan ${ }^{2}$ \\ Universitas Terbuka UPBJJ Malang Jl Mayjen Sungkono No. 9 Malang $^{3}$ \\ asnah@ut.ac.id ${ }^{1}$,sondangp@ut.ac.id ${ }^{2}$,dan herna@ut.ac.id ${ }^{3}$
}

\begin{abstract}
Abstrak: Tujuan penelitian ini adalah untuk mengetahui tingkat kepuasan Mahasiswa terhadap pelayanan UPBJJ-UT Medan dan ada atau tidaknya pengaruh signifikan variabel keandalan (reliability), ketanggapan (responsivenes), keyakinan (assurance), empati (emphaty), dan berwujud (tangible) terhadap kepuasan Mahasiswa secara parsial maupun simultan. Penentuan sampel menggunakan nonprobability sampling, yaitu dengan cara aksidental sampling, artinya penentuan sampel berdasarkan penyebaran kuisioner, yaitu mengirimkan 441 kuisioner ke 26 wilayah pelaksanaan tutorial melalui jasa penanggungjawab wilayah. Hasil penelitian ini menunjukkan bahwa tingkat kepuasan mahasiswa terhadap pelayanan yang diberikan berada dalam kategori tinggi. Secara simultan, pelayanan UPBJJ-UT Medan berpengaruh signifikan terhadap kepuasan mahasiswa. Secara parsial diketahui pelayanan dari faktor keandalan, faktor ketanggapan dan faktor berwujud berpengaruh signifikan terhadap kepuasan mahasiswa sedangkan pelayanan dari faktor keyakinan dan faktor empaty tidak mempunyai pengaruh yang signifikan terhadap kepuasan mahasiswa. Pelayanan dari faktor keandalan yang paling berpengaruh secara dominan dalam terciptanya kepuasan mahasiswa berkuliah di Universitas Terbuka UPBJJ Medan.
\end{abstract}

Kata Kunci: Kepuasan Mahasiswa, Pelayanan, Faktor Keandalan, Faktor Ketanggapan, Faktor Keyakinan, Faktor Empaty dan Faktor Berwujud.

Abstract: The research purpose in this article was to determine (1) the level of students satisfaction to the services provided by the Indonesian Open University Regional Medan (UPBJJ-UT Medan), (2) the influence of reliability, responsivenes, assurance, emphaty and tangible to students satisfaction. The sample was selected using nonprobability sampling, in particular by accidental sampling, which means that sampling is based on questionnaires, which is sending 441 questionnaires to 26 regions of face-to-face tutorial. The results showed that the level of students satisfaction to the services provided was in the high category. Simultaneously, the service provided by UPBJJ-UT Medan significantly influenced to students satisfaction. Partially, it was showed that the reliability, responsiveness and tangible factors of service significantly influence students satisfaction while assurance and empathy factors of service did not have a significant impact on students satisfaction. Reliability factor of service most dominant influences student satisfaction in studying at UPBJJ-UT Medan.

Keywords: Students Satisfaction, Service, Reliability Factor, Responsiveness Factor, Assurance Factor, Tangible Factor, Empaty Factor

\section{PENDAHULUAN}

UPBJJ-UT Medan sebagai salah satu unit pelayanan belajar jarak jauh UT telah mengupayakan memberikan pelayanan untuk memenuhi kebutuhan mahasiswa, namun dalam perjalanannya sering mendapat keluhan dari mahasiswa. Keluhan mahasiswa tentang semakin sulitnya untuk mendapatkan pelayanan yang baik tampaknya masih menjadi kendala yang sepenuhnya belum dapat diatasi oleh UPBJJ-UT Medan.

Keluhan-keluhan terhadap pelayanan UPBJJ-UT Medan, baik dari mahasiswa maupun calon mahasiswa menyebabkan mahasiswa menjadi kurang puas, antara lain dalam administrasi pelayanan yang belum memenuhi target atau standar pelayanan, lokasi atau tempat pelaksanaan tutorial, distribusi 
modul yang belum tepat waktu serta kecepatan penanganan keluhan yang kurang efektif sehingga membutuhkan waktu lebih dari yang diharapkan oleh mahasiswa. Penanganan keluhan memberikan peluang untuk mengubah seorang mahasiswa tidak puas menjadi mahasiswa yang puas. Proses penanganan keluhan yang efektif mulai dengan identifikasi disertai dengan penentuan sumber yang menyebabkan mahasiswa tidak puas dan mengeluh.

Mahasiswa UPBJJ-UT Medan dari tahun ke tahun ada kecenderungan mengalami peningkatan. Kalau dilihat jumlah Mahasiswa pada periode tahun 2007-2008, jenis Mahasiswa yang paling banyak adalah Mahasiswa yang berprofesi Guru (Program Pendas). Untuk mengantisipasi peningkatan jumlah mahasiswa sebagai akibat dari adanya komitmen dukungan pemerintah daerah, UPBJJ-UT Medan telah mengupayakan beberapa potensi kualitas pelayanan UPBJJ-UT Medan yang menyangkut (1) Keandalan (Reliability) diukur berdasarkan kemampuan UPBJJ-UT Medan yang berkaitan dengan kesiapan petugas setiap saat diperlukan, ketepatan waktu pelayanan, dan berkaitan dengan ada tidaknya pembedaan Mahasiswa satu dengan lainnya dalam melaksanakan pelayanan dengan tepat dan terpercaya, (2) Ketanggapan (Responsivenes) diukur berdasarkan kemampuan UPBJJ-UT Medan yang berkaitan dengan ketanggapan petugas atas keluhan dan masalah yang dihadapi Mahasiswa, (3) Keyakinan (Assurance) diukur berdasarkan kemampuan UPBJJ-UT Medan yang berkaitan,dengan keramahan dan kesopanan, pemberian pelayanan secara tuntas dan menyeluruh serta memberikan penjelasan dengan baik dalam menimbulkan kepercayaan dan Empati (Emphaty) diukur berdasarkan kemampuan UPBJJ-UT Medan yang berkaitan dengan sikap dan perhatian petugas, berlaku adil pada setiap Mahasiswa, dan berpenampilan baik dalam memberi perhatian secara individu kepada Mahasiswa, dan (5) Berwujud (Tangible) diukur berdasarkan kemampuan UPBJJ-UT Medan yang berkaitan dengan tempat pelayanan yang nyaman dan memadai, peralatan dan perlengkapan yang baik, serta prosedur pelayanan yang sama bagi semua pihak dalam menampilkan fasilitas fisik, peralatan, personel, dan media komunikasi/ informasi.

Konsep pelayanan menurut Kuncoro,
Sudirman, dan Lukman (1999) adalah kegiatan-kegiatan yang tidak jelas, namun menyediakan kepuasan konsumen dan atau pemakai industri serta tidak terikat pada penjualan suatu produk atau pelayanan lainnya. Lebih lanjut dikatakan bahwa pelayanan adalah suatu urutan kegiatan yang terjadi dalam interaksi langsung dengan orang-orang atau mesin secara fisik dan menyediakan kepuasan konsumen. Kepuasan konsumen (Customer Satifaetion) atau sering disebut juga dengan Total Customer Satisfaction menurut Barkley dan Saylor (1994) merupakan fokus dari proses Costomer-Driven Project Management (CDPM), bahkan dinyatakan pula bahwa kepuasan konsumen adalah kualitas. Begitu juga definisi singkat tentang kualitas yang dinyatakan oleh Djumara (2000) bahwa kualitas adalah kepuasan konsumen. .

Menurut Kotler yang dikutip Tjiptono (1996) bahwa kepuasan Konsumen adalah tingkat perasaan seseorang setelah membandingkan kinerja (atau hasil) yang dirasakan dengan harapannya.Jadi, tingkat kepuasan adalah fungsi dari perbedaan antara kinerja yang dirasakan dengan harapan.

Berdasarkan latar belakang di atas dapat dirumuskan masalah sebagai berikut

a. Seberapa tinggi tingkat kepuasan Mahasiswa terhadap pelayanan UPBJJ-UT Medan?

b. Adakah pengaruh signifikan secara bersamasama keandalan (reliability),ketanggapan (responsivenes), keyakinan (assurance), empati (emphaty), dan terwujud (tangible) terhadap kepuasan Mahasiswa UPBJJ-UT Medan?

c. Bagaimanakah pengaruh keandalan (reliability), ketanggapan (responsiveness), keyakinan (assurance), empati (emphaty), dan berwujud (tangible)secara parsial terhadap kepuasan Mahasiswa UPBJJ-UT Medan?

Artikel ini ditulis berdasarkan hasil penelitian yang bertujuan untuk mengetahui (1) seberapa tinggi tingkat kepuasan mahasiswa terhadap pelayanan UPBJJ-UT Medan, (2) ada atau tidaknya pengaruh signifikan secara bersama-sama keandalan (reliability), ketanggapan (respomiverm). kevakinan(assurance), empati (emphan), dan berwujud (tangible) terhadap kepuasan Mahasiswa UPBJJ-UT Medan, (3) pengaruh keandalan (reliability), ketanggapan (responsivenes). Keyakinan (assurance), empati (emphaly), dan berwujud (tangible) secara 
parsial terhadapkepuasan Mahasiswa UPBJJUT Medan.

\section{METODE}

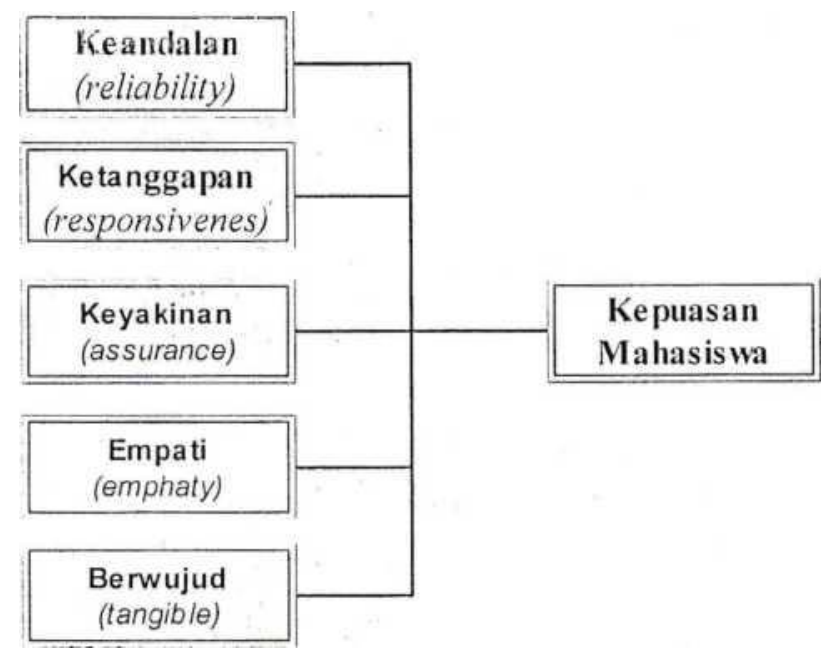

Populasi dalam artikel penelitian ini adalah mahasiswa Program Pendidikan Dasar (Pendas) Universitas Terbuka di wilayah UPBJJ Medan. Waktu penelitian dilakukan selama 6 bulan mulai April sampai dengan Oktober 2009. Kerangka konseptual penelitiannya adalah sebagai berikut:
Hipotesis penelitian dalam artikel ini adalah (1) Ada pengaruh signifikan secara bersama-sama faktor keandalan (reliability), ketanggapan (responsivene.s), keyakinan (assurance), empati (emphaty), dan berwujud (tangible) terhadap kepuasan Mahasiswa UPBJJ-UT Medan, (2) Ada pengaruh positif dan signifikan faktor keandalan (reliability), ketanggapan (responsivenes), keyakinan (assurance), empati (emphaty), serta berwujud (tangible) secara parsial terhadap kepuasan Mahasiswa UPBJJ-UT Medan . Sesuai dengan tujuan penelitian dan hipotesis penelitian dalam studi ini maka 441 kuesioner didistribusikan ke 26 wilayah pelaksanaan tutorial tatap muka di Sumatera Utara.

Ukuran sampel ditentukan dengan menggunakan rumus Slovin (Consuelo dkk., 1998).. Penentuan sampel menggunakan nonprobability sampling, yaitu dengan cara aksidental sampling, artinya penentuan sampel berdasarkan penyebaran kuisioner, yaitu mengirimkan 441 kuisioner ke 26 wilayah pelaksanaan Tutorial melalui jasa staf Penanggung jawab Wilayah. Data yang diperoleh dianalisis secara deskriptif dengan menggunakan persentase, nilai rata-rata dan standard deviasi dan secara inferensial dengan menggunakan uji $\mathrm{F}$ dan uji t.

\section{HASIL DAN PEMBAHASAN}

\section{Hasil}

Sesuai dengan tujuan penelitian dalam artikel ini faktor-faktor yang mempengaruhi kepuasan mahasiswa terhadap pelayanan UPBJJ-UT Medan meliputi keandalan (reliability), ketanggapan (responsivenes), keyakinan (assurance), empati (emphaty), dan berwujud (tangible). Hasil analisis deskriptif terhadap data yang diperoleh adalah sebagai berikut.

\section{Keandalan (Reliability)}

Variabel Keandalan (reliability) terdiri atas lima indikator yang meliputi hal-hal berikut: (1) staf UT selalu siap sewaktu dibutuhkan, (2) Staf UT mempunyai ketepatan waktu dalam pelayanan, (3) staf UT tidak ada membedakan mahasiswa dalam melaksanakan pelayanan, (4) akurasi data registrasi mahasiswa, (5). ketepatan jadwal tutorial/praktek/praktikum Dari jawaban responden terhadap kelima indikator tersebut diketahui bahwa kegiatan pelayanan terhadap mahasiswa dari aspek keandalan telah mencerminkan keinginan mahasiswa.

Ini dibuktikan dengan 46,9 persen responden menyatakan setuju dan 24,7 persen responden menyatakan sangat setuju bahwa staf UT selalu siap sewaktu dibutuhkan. 44,9 persen responden menyatakan setuju, 22,2 persen menyatakan jawaban sangat setuju bahwa kegiatan pelayanan telah dapat 
menepati waktu yang telah ditetapkan. 41,5 persen responden atau mahasiswa menunjukan sangat setuju dan 49,2 persen menunjukkan sangat setuju bahwa Staf UT telah berupaya untuk tidak melakukan diskriminasi pelayanan. 23,8 persen responden atau mahasiswa menunjukan sangat setuju dan 56.9 persen menunjukkan sangat setuju terhadap akurasi data mahasiswa. 80,9 persen responden yang setuju dan sangat setuju tentang ketepatan jadvval UPBJJ UT Medan dalam melakukan pelayanan tutorial/praktek/praktikum. Namun, sebahagian kecil mahasiswa masih menyatakan sangat tidak setuju, tidak setuju, dan biasa saja terhadap beberapa indikator di atas, antara lain: (1) tingkat pelayanan dirasakan sepenuhnya belum mampu diberikan setiap saat, (2)sebagian kecil kegiatan pelayanan dilaksanakan kurang memenuhi jadwal yang telah ditetapkan.

\section{Ketanggapan (Responsiveness)}

Variabel ketanggapan (responsiveness) terdiri atas lima indikator yang meliputi hal-hal berikut. (1) ketanggapan staf UT atas keluhan dan masalah yang dihadapi mahasiswa, (2) staf UT cepat dalam menanggapi mahasiswa/calon yang membutuhkan bantuan, (3) Kemampuan UPBJJ UT medan yang baik untuk turun ke pokjar dalam merespon permasalahan mahasiswa, (4) staf UT bersedia melakukan kunjuangan ke pokjar untuk membimbing registrasi mahasiswa dengan baik, (5) adanya katalog/ modul gratis yang bagus, jelas dan lengkap bagi mahasiswa setiap tahun.

Dari jawaban responden terhadap kelima indikator tersebut diperoleh gambaran bahwa ketanggapan Staf UT dalam menangani masalah yang berkaitan dengan mahasiswa sudah baik. Ini dibuktikan dengan 49,0 persen responden setuju dan 23,8 persen responden sangat setuju terhadap cepat tanggapnya Staf dengan keluhan mahasiswa, 48,1 persen responden setuju dan 25,9 persen responden sangat setuju.terhadap kecepatan staf UT menanggapi mahasiswa/calon mahasiswa yang membutuhkan bantuan, 49,4 persen responden menyatakan setuju dan 24,3 persen menyatakan sangat setuju dengan pernyataan kemampuan UPBJJ UT medan yang baik untuk turun ke pokjar dalam merespon permasalahan mahasiswa, 41,3 persen setuju dan 31,7 persen responden sangat setuju.terhadap pernyataan staf UT bersedia melakukan kunjuangan ke pokjar untuk membimbing registrasi mahasiswa dengan baik, 31,3 persen dan 57,1 persen responden menunjukkan setuju dan sangat setuju terhadap pernyataan adanya katalog/ modul gratis yang bagus, jelas dan lengkap bagi mahasiswa setiap tahun.

Namun, sebahagian kecil mahasiswa masih menyatakan sangat tidak setuju dan tidak setuju terhadap beberapa indikator di atas, antara lain: (1) tingkat ketanggapan staf UT atas keluhan dan masalah yang dihadapi mahasiswa masih belum sesuai dengan harapan mahasiswa, (2) kecepatan staf UT dalam menanggapi mahasiswa/calon yang membutuhkan bantuan masih dirasakan kurang, (3), kesediaan staf UT untuk melakukan kunjuangan ke pokjar untuk membimbing registrasi mahasiswa dengan baik masih dirasakan kurang, (4) adanya katalog/ modul gratis yang bagus, jelas dan lengkap bagi mahasiswa setiap tahun masih belum diketahui beberapa mahasiswa yang berarti bahwa tingkat pelayanan modul/katalog di UT masih perlu ditingkatkan dalam usaha memberi.yang lebih baik.

\section{Keyakinan (Assurance)}

Variabel Keyakinan(Assurance) terdiri atas lima indikator yang meliputi hal-hal berikut: (1) staf UT ramah dan sopan dalam memberikan pelayanan, (2) staf UT berpakaian rapih saat bekerja, (3) staf UT memberikan informasi dengan ramah, (4) staf UT memberikan pelayanan secara tuntas dan menyeluruh, (5) staf UT mampu memberikan penjelasan dengan baik dalam menimbulkan kepercayaan dan keyakinan.

Dari jawaban responden terhadap kelima indikator tersebut diperoleh gambaran bahwa keyakinan mahasiswa UT terhadap pelayanan yang diberikan sudah baik. Ini dibuktikan dengan 45,1 persen responden setuju dan 42,6 persen responden sangat setuju atas keramahan dan kesopanan Staf UT dalam memberikan pelayanan, 47,4 persen responden setuju dan 44,4 persen responden sangat setuju atas kerapihan berpakaian Staf UT saat bekerja, 46 persen responden setuju dan 37,9 persen responden sangat setuju atas keramahan Staf UT dalam memberikan informasi, 44,2 persen responden menyatakan setuju dan sebanyak 26,8 persen responden menyatakan sangat setuju terhadap pernyataan staf UT memberikan pelayanan secara tuntas dan menyeluruh, 48,1 persen responden menyatakan setuju dan 29,3 persen responden menyatakan sangat setuju terhadap pernyataan Staf UT mampu 
memberikan penjelasan dengan baik dalam menimbulkan kepercayaan dan keyakinan. Namun dari angket juga diketahui bahwa sebagian kecil mahasiswa masih merasakan (1) kurang mendapat keramahan pelayanan, , (2) sebagian kecil Staf UT tidak berpenampilan rapih dalam bekerja, (3) kurang mendapat keramahan dalam layanan informasi, (4) sebagian kecil staf UT belum memberikan pelayanan secara tuntas dan menyeluruh, (5) sebagian staf UT belum mampu memberikan penjelasan dengan baik.

\section{Empati (Emphaty)}

Variabel Empati (Emphaty) terdiri atas lima indikator yang meliputi hal-hal berikut: (1) staf UT bersikap penuh perhatian dalam memberikan pelayanan, (2) staf UT memberikan rasa adil kepada setiap mahasiswa, (3) Staf UT berpenampilan baik dalam memberikan perhatian secara individu kepada mahasiswa, (4) proses administrasi UT yang sistematis dan dapat diandalkan, (5) proses kerja yang cepat dan sederhana. Dari jawaban responden terhadap kelima indikator tersebut diketahui bahwa kualitas pelayanan UT dari aspek empati sudah baik. Ini dibuktikan dengan 51,5 persen responden menyatakan setuju dan 20,6 persen responden menyatakan sangat setuju dengan pernyataan staf UT bersikap penuh perhatian dalam memberikan pelayanan, 28,1 persen responden sangat setuju dan 54,4 persen responden setuju terhadap pernyataan staf UT memberikan rasa adil kepada setiap mahasiswa, 26.3 persen responden menyatakan sangat setuju dan 51,9 persen responde setuju dengan penampilan baik yang ditunjukkan Staf UT dalam melaksanakan tugas, 21,3 persen responden sangat setuju dan 49,9 persen responden setuju dengan pernyataan proses administrasi UT sistematis dan dapat diandalkan, 22,4 persen responden menyatakan sangat setuju dan 49,7 persen responden menyatakan setuju terhadap pernyataan proses kerja yang cepat dan sederhana dari staf UT dalam melaksanakan tugas. Namun dari angket juga diketahui bahwa sebagian kecil mahasiswa masih merasakan: (1) tidak mendapatkan perhasiari penuh dari Staf UT., (2) sebagian staf UT belum memberikan rasa adil dalam pelayanan kepada setiap mahasiswa, (3) beberapa Staf UT pemberi jasa pelayanan kurang memperhatikan penampilan, (4) proses administrasi UT belum sistematis dan dapat diandalkan, (5) proses kerja sebahagian staf belum cepat dan sederhana.

\section{Berwujud (Tangible)}

Variabel Berwujud (Tangible) terdiri atas lima indikator yang meliputi hal-hal berikut: (1) tempat pelayanan yang nyaman dan memadai, (2) peralatan dan perlengkapan yang baik, (3) prosedur pelayanan yang sama bagi semua pihak, (4) lokasi UPBJJ yang mudah terjangkau, (5) kemudahan melakukan pembayaran biaya pendidikan. Dari jawaban responden terhadap kelima indikator tersebut diketahui bahwa kualitas pelayanan UT dari aspek berwujud sudah baik. Ini dibuktikan dengan 47,8 persen menyatakan setuju, kemudian 21.5 persen responden menyatakan sangat setuju denganpernyataan tempat pelayanan nyaman dan memadai, 15,9 persen responden menunjukkan sangat setuju dan 44,0 persen responden menyatakan setuju bahwa peralatan dan perlengkapan UT baik, 21,8 persen responden menyatakan sangat setuju dan 59,6 persen responden menyatakan setuju bahwa prosedur pelayanan yang diberikan sama bagi semua pihak, 24,7 persen responden menunjukkan sangat setuju dan 54,4 persen responden menyatakan setuju bahwa lokasi UPBJJ mudah terjangkau, 27,4 persen responden menyatakan sangat setuju dan 46.3 persen responden menyatakan setuju dengan pernyataan kemudahan melakukan pembayaran biaya pendidikan. Namun dari angket juga diketahui bahwa sebagian kecil mahasiswa masih merasakan: (1) ruang pelayanan yang disediakan pada bagian tertentu masih perlu mendapat perhatian UPBJJ-UT, (2) keberadaan sebahagian kecil peralatan dan perlengkapan untuk menunjangkelancaran pelayanan saat ini kondisinya kurang memadai sehingga memerlukan pcralatan yang baru, (3) lokasi UPBJJ-UT Medan tidak mudah terjangkau, (4) belum ada kemudahan melakukan pembayaran biayap penididikan.

\section{Kepuasan Mahasiswa (Y)}

Variabel dependen kepuasan mahasiswa terdiri atas lima indikator yang meliputi hal-hal berikut: (1) staf UT menguasai informasi yang dibutuhkan mahasiswa, (2) staf UT memberikan informasi dengan jelas, (3) tempat pelaksanaan tutorial yang layak, (4) tempat penyelenggaraan ujian yang layak, (5) staf UT cepat dalam menanggapi keluhan mahasiswa.

Berdasarkan jawaban responden dapat 
diketahui bahwa mahasiswa puas terhadap pelayanan yang diberikan oleh UT. Ini dibuktikan dengan 37,2 persen responden menyatakan sangat setuju dan 50,3 persen responden yang menyatakan setuju bahwa staf UT menguasai informasi yang dibutuhkan mahasiswa, $\quad 33,3$ persen responden menyatakan sangat jelas dengan informasi yang disampaikan Staf UT, dan 48,8 persen responden menyatakan cukup jelas, 24,9 persen responden menyatakan sangat puas dan 43,5 persen responden menyatakan puas dengan tempat pelaksanaan tutorial, 24,9 persen responden menyatakan sangat puas dan 42,4 persen responden menyatakan puas dengan tempat pelaksanaan ujian, 25,6 persen responden menyatakart kecepatan penanganan keluhan sangat memuaskan mahasiswa dan 49,0 persen responden puas atas kecepatan penanganan keluhan, Namun dari angket juga diketahui bahwa sebagian kecil mahasiswa masih merasakan: (1) ada informasi yang disampaikan oleh Staf UT ke mahasiswa belum dapat sepenuhnya dilakukan dengan baik sesuai dengan harapan mahasiswa, (2) perlu untuk menambah lokasi tutorial dalam upaya menghindari padatnya jumlah mahasiswa dalam 1 lokasi dan jarak vang ditempuh mahasiswa, (3) perlu untuk meningkatkan fasilitas lokasi ujian yang lebih memadai, (4) sebahagian staf UT belum cepat dalam menanggapi keluhan Mahasiswa.

\section{Tingkat Kepuasan Mahasiswa UPBJJ-UT Medan}

Berdasarkan jawaban responden diperoleh rata-rata tingkat kepuasan $(\mathrm{X})$ dari Staf UT penguasaan informasi yang dibutuhkan mahasiswa, kejelasan informasi yang diberikan Staf UT, tempat penyelenggaraan tutorial, tempat penyelenggaraan ujian dan kecepatan staf UT dalam menanggapi keluhan mahasiswa sebesar 2,02, standar deviasi (SD) sebesar 0,66. Kemudian Nilai Indikator (I) dari tiap-tiap faktor, yaitu untuk Staf UT penguasaan informasi yang dibutuhkan mahasiswa indikatornya sebesar 1,78, kejelasan informasi yang diberikan Staf UT sebesar 1,89, nilai indikator tempat penyelenggaraan tutorial sebesar 2,12, nilai indikator tempat penyelenggaraan ujian sebesar 2,15 dan kecepatan penanganan keluhan nilai indikatornya sebesar 2,16 .

Berdasarkan kategori tingkat kepuasan mahasiswa yang diukur dari Staf UT menguasai informasi yang dibutuhkan mahasiswa diperoleh 2,02 - 0,66<1.78<2,02 atau X - SD $<$ I $<$ X sehingga skor tersebut berada dalam kategori tingkat kepuasan sedang. Hal ini menunjukkan bahwa kualitas pelayanan UPBJJUT Medan dari Staf UT penguasaan informasi sudah dapat memenuhi kebutuhan, keinginan, dan harapan mahasiswa secara optimal. Demikian juga halnya dengan tingkat kepuasan mahasiswa UPBJJ-UT Medan yang diukur dari kejelasan informasi yang diberikan Staf UT diperoleh 2,02 - 0,66 $<1.98<2,02$ atau X - SD $<1<\mathrm{X}$. Skor tersebut berada dalam kategori tingkat kepuasan Tinggi.

Hal ini menunjukkan bahwa kualitas pelayanan UPBJJ-UT Medan dari kejelasan informasi yang diberikan Staf UT sudah dapat memenuhi kebutuhan, keinginan, dan harapan mahasiswa secatp optimal. Kemudian tingkat kepuasan mahasiswa yang diukur dari tempat peftyclengganaiin tutorial diperoleh 3,19>2,75 $+0,42$ atau $\mathrm{I}>\mathrm{X}+\mathrm{SD}$. Skor tersebut berada dalam kategori, tingkat kepuasan tinggi. Ini berarti bahwa kualitas pelayanan dari pelaksanaan tutorial pan lokasi tutorial dirasakan sudah memenuhi harapan mahasiswa. Tingkat kepuasan mahasiswa yang diukur dari kecepatan penanganan?keluhan diperoleh 2,75 $0,42<2,51<2,75$ atau X - SD $<1<X$. Skor tersebut berada dalam kategori tingkat kepuasan tinggi. Ini berarti bahwa kualitas pelayanan UPBJJ-UT Kota Medan dari kecepatan penangan keluhan dirasakan sudah memenuhi harapan dari mahasiswa.

Berdasarkan uraian tersebut dapat diketahni bahwa tingkat kepuasan mahasiswa .UPBJJ- UT Kota Medan sudah mencapai tingkat yang optimal, Ini menunjukkan bahwa tjngkat pelayanan yang diberikan oleh UPBJJUT Medan yang menyangkut keempat aspek yang telah diuraikan sebelumnya dirasa sudah memenuhi harapan mahasiswa sehingga; tingkat kepuasan mahasiswa yang diterima saat ini sudah optimal.

Sccara inferensial, hasil ini masih harus dibuktikan melalui analisis uji $\mathrm{F}$ dan uji $\mathrm{t}$ namun sebelumnya dilakukan terlebih dahulu uji persyaratan penggunaan analisis (uji asumsi klasik). Asumsi-asumsi klasik yang harus dipenuhi antara lain terbebas dari auto korelasi, multikolineritas, heterokedastisitas, dan harus memenuhi normalitas (Kuncoro 2001). Hasil Pengujian menunjukkan semua asumsi klasik dipenuhi sehingga uji $\mathrm{F}$ dan $\mathrm{t}$ dapat digunakan. 
Selanjutnya dilakukan pengujian hipotesis secara serempak dengan menggunakan uji $\mathrm{F}$ untuk mengetahui apakah variabel-variabel independen Variabel keandalan (XI), variabel ketanggapan (X2), variabel keyakinan (X3), variabel empaty (X4), dan variabel berwujud (X5), secara bersama-sama berpengaruh secara signiflkan terhadap .variabel dependen kepuasan mahasiswa terhadap pelayanan UPBJJ-UT Medan. Pengaruh variabel - variabel independen tersebut dapat dilihat pada tabel berikut ini :

Tabel 1. Tabel A nova

\begin{tabular}{llcccl}
\hline & & Sum of & & \\
Model & & Squares & df & F & Sig: \\
1 & Regression & 104,564 & 5 & 103,000 & $.000(\mathrm{a})$ \\
& Residual & 88,321 & 435 & & \\
& Total & 192,886 & 440 & & j. - - r \\
\hline
\end{tabular}

a Predictors: (Constant), berwujud, ketanggapan, keandalan, keyakinan, empaty b Dependent Variable: kepuasan mahasiswa

Dari Tabel 1 diperoleh nilai $\mathrm{F}$ |lltung sebesar 103,00 sedangkan nilai signifikan $\mathrm{F}$ nya adalah sebesar 0,000 . Hal ini berarti bahwa nilai signifikan $\mathrm{F}$ lebih kecil dari a $=0,05$. Hal ini memberikan arti bahwa variabel-variabel independen variabel Keandalan (XI), variabel Ketanggapan (X2), variabel Keyakinan (X3), variabel Empaty (X4), dan variabel Berwujud (X5) secara bersama-sama mempunyai pengaruh yang signifikan terhadap Kepuasan'Mahasiswa (Y) di UPBJJ-UT Medan. Sedangkan besarnya koefisien determinasi $\left(\mathrm{R}^{2}\right)$ hipotesis dapat dilihat pada tabel 3 dibawah ini:

Tabel 2

Koefisien Determinasi (R)

$\begin{array}{lclc}\text { Model } & \mathbf{R} & \text { R Square } & \text { Adjusted R } \\ 1 & \mathbf{. 7 3 6}(\mathbf{a}) & , \mathbf{5 4 2} & \text { Square I, ,537 }\end{array}$

a Predictors: (Constant), berwujud, ketanggapan, keandalan, keyakinan, empaty b Dependent Variable: KEPUASAN MAHASISWA

Dari Tabel 2 di atas dapat dilihat bahwa adjusted R square adalah sebesar 0.537. Hal ini menunjukkan bahwa dari variabel-variabel independen yang terdiri dan.variabel Keandalan , (X 1), variabel Ketanggapan (X2), variabel Keyakinan (X3), variabel Empaty (X4), variabel Berwujud (X5) menunjukkan kemampuan variasi menjelaskan 53,7 persen terhadap variabel Kepuasan Mahasiswa (Y) di UPBJJ-UT Medan. Sedangkan sisanya 46,3\% merupakan pengaruh dari variabel-variabel lain yang tidak diikutsertakan dalam analisis ini.

Secara Parsial, Pengujian hubungan antara variabel-variabel independen $(\mathrm{X})$ terhadap $(\mathrm{Y})$ adalah sebagai berikut: 
Tabel 3. Uji“"t”

Dependent Variable: KEPUASAN MAHASISWA

\begin{tabular}{|c|c|c|c|c|c|}
\hline & \multicolumn{2}{|l|}{ Coefficients } & \multirow{2}{*}{\begin{tabular}{|c|}
$\begin{array}{l}\text { Coefficients } \\
\text { Standardized }\end{array}$ \\
Beta \\
\end{tabular}} & \multirow[t]{2}{*}{$t$} & \multirow[t]{2}{*}{ Sig. } \\
\hline & Std. & Error & & & \\
\hline (Constant) & ,256 & 083 & & 3,103 &, 002 \\
\hline KEANDALAN & ,384 & 053 & .367 & 7,216 &, 000 \\
\hline KETANGGAPAN & ,233 & 055 & ,225 & 4,265 &, 000 \\
\hline KEYAKINAN & ,099 & 061 & ,093 & 1,615 & 1,107 \\
\hline EMPATY & ,008 & 071 &, 008 & $* ! i, 1: 12^{\wedge}$. & !,ii: .911 \\
\hline BERWUJUD & , 163 & 049 & , 159 & $: 3,34 q \mid i ;$ & $\begin{array}{l}\text { Ifei } \\
. O O^{\wedge} I V T\end{array}$ \\
\hline
\end{tabular}

a. Pengujian variabel Keandalan (XI) terhadap Kepuasan Mahasiswa (Y).

Dari Tabel 3 di atas, diperoleh hasil signifikan $t$ pengaruh variable-variabcl Keandalan (XI) sebesar 0.000, dimana signifikan $\mathrm{t}$ lebih kecil dari $\mathrm{u}=0,05$. Hal ini berarti bahwa Ho ditolak sedangkan $\mathrm{H} 1$ diterima dan dapat disimpulkan bahwa Faktor Keandalan secara parsial mempunyai pengaruh yang signifikan terhadap Kepuasan Maliasiswa UPBJJ-UT Medan.. Disamping itu juga ditemukan bahwa Faktor Keandalan secara konsisten merupakan variabel yang paling dominan mempengaruhi Kepuasan Mahasiswa (yang ditunjukkan dengan beta standar terbesar yaitu 0.367), lebih dominan dibandingkan dengan faktor-faktor lainnya.

\section{b. Pengujian variabel Ketanggapan (X2)}

terhadap Kepuasan Maliasiswa (Y) 1

Dari Tabel 3 di atas, diperoleh hasil signifikan $\mathrm{t}$ pengaruh variabel Ketanggapan (X2) sebesar 0.000 , dimana signifikan t lebih kecil dari a $=0,05$. hal tersebut berarti bahwa H0 ditolak sedankan H1 diterima dan dapat disimpulkan bahwa faktor Ketanggapan secara parsial mempunyai pengaruh yang signifikan terhadap Kepuasan Maliasiswa UPBJJ-UT Medan.

c. Pengujian variabel Keyakinan (X3) terhadap Kepuasan Mahasiswa (Y)

Dari Tabel 3 di atas, diperoleh hasil signifikan t pengaruh variabel Keyakinan (X3) sebesar 0.107, dimana signifikan t lebih besar dari a $=0,05$. hal tersebut berarti bahwa Ho diterima sedankan $\mathrm{H} 1$ ditolak dan dapat disimpulkan bahwa faktor Keyakinan secara parsial tidak mempunyai pengaruh yang signifikan terhadap Kepuasan Mahasiswa UPBJJ-UT Medan.

d. Pengujian variabel Empaty (X4) terhadap Kepuasan Maliasiswa (Y)

Dari Tabel 3 di atas, diperoleh hasil signifikan $\mathrm{t}$ pengaruh variabel Empaty (X4) sebesar 0.911, dimana signifikan t lebih besar dari a $=0,05$. hal tersebut berarti bahwa Ho diterima sedankan $\mathrm{H} 1$ ditolak dan dapat disimpulkan bahvva Faktor Empaty: secara,parsiial tidak meinpunyai pengaruh yang signifikan terhadap Kepuasan Maliasiswa UPBJJ-UT Medan.

e. Pengujian variabel Berwujud (X5) terhadap Kepuasan Maliasiswa (Y).

Dari Tabel 3 di atas, diperoleh hasil signifikan t pengaruh variabel Berwujud (X5) sebesar 0.000 , dimana signifikan $t$ lebih kecil dari a $=0,05$. hal tersebut berarti bahwa Ho ditolak sedangkan $\mathrm{H} 1$ diterima dan dapat disimpulkan bahwa Faktor Berwujud secara parsial mempunyai pengaruh yang signifikan terhadap Kepuasan Mahasiswa UPBJJ-UT Medan. 


\section{Analisa Persamaan Regresi}

Berdasarkan Tabel 3 di atas, maka model analisis regresi beganda antara variabel $\mathrm{X}$ terhadap Y dapat diformulasikan dalam model persamaan sebagai berikut :

$Y=0,256+0,384 X I+0.233 X 2+0.163 X 5$

Dari hasil persamaan regresi berganda tersebut, masing-masing variabel independen dapat diinterprestasikan pengaruhnya terhadap kepuasan mahasiswa sebagai berikutt :

1. Variabel Ketanggapan (X2) memiliki koefisien bertanda positif sebesar 0.233 , hal tersebut berarti apabila nilai koefisien regresi variabel lainnya tetap (tidak berubah), maka perubahan Faktor Ketanggapan sebesar $1 \%$ akan meningkatkan Kepuasan Mahasiswa di UPBJJ-UT Medan sebesar 23,3\%.

2. Variabel Berwujud (X5) memiliki koefisien bertanda positif sebesar 0.163 . hal tersebut berarti apabila nilai koefisien regresi variabel lainnya tetap (tidak berubah) maka perubahan Faktor Berwujud sebesar 1\% akan meningkatkan Kepuasan Mahasiswa di UPBJJ-UT Medan sebesar 16,3\%.

\section{PENUTUP \\ Simpulan}

Berdasarkan pembahasan penelitian

dapat diambil atau dikemukakan beberapa

simpulan.yaitu sebagai berikut.

1. Tingkat kepuasan mahasiswa UPBJJ-UT Kota Medan sudah mencapai tingkat yang optimal. Ini menunjukkan bahwa tingkat pelayanan yang diberikan oleh UPBJJ-UT Medan yang menyangkut Staf UT penguasaan informasi yang dibutuhkan mahasiswa, kejelasan informasi yang diberikan Staf UT, tempat penyelenggaraan tutorial dan kecepatan penanganan keluhan. yang diuraikan sebelumnya dirasa sudah memenuhi harapan mahasiswa sehingga tingkat kepuasan mahasiswa yang diterima saat ini sudah optimal.

2. Secara bersama-sama atau simultan seluruh variabel, yaitu faktor keandalan (reliability) (X1), faktor ketanggapan (responsiveness) (X2), faktor keyakinan (assurance) (X3), faktor emnati (emphaty) (X4), dan faktor berwujud (tangible) (X5) berpengaruh secara nyata dan positif terhadap kepuasan mahasiswa UPBJJ-UT Medan .

3. Secara parsial faktor faktor keandalan (reliability) (X1), ketanggapan (responsiveness/ (X2). dan, faktor berwujud (tangible)(X5) berpengaruh nyata dan positif terhadap kepuasan: mahasiswa UPBJJ-UT Medan. Sedangkan faktor keyakinan (assurance)(X3) dan faktor empati (emphaty) (X4) secara,parsiial tidak meinpunyai pengaruh yang signifikan terhadap Kepuasan Maliasiswa UPBJJ-UT Medan.

4. Disamping itu juga ditemukan bahwa Faktor Keandalan secara konsisten merupakan variabel yang paling dominan mempengaruhi Kepuasan Mahasiswa (yang ditunjukkan dengan beta standar terbesar yaitu 0.367), lebih dominan dibandingkan dengan faktor-faktor lainnya.

\section{Saran}

Saran yang dapat diberikan antara lain:

1. UPBJJ-UT Medan dalam operasinya perlu semakin meningkatkan kualitas pelayanan untuk mencapai tingkat kepuasan mahasiswa yang lebih optimal.

2. UPBJJ-UT Medan perlu mencermati upaya pemenuhan pelayanan kepada mahasiswa dengan menguasai informasi yang dibutuhkan mahasiswa, sebab pelayanan informasi kepada mahasiswa masih belum optimal, oleh karena itu staf UPBJJ-UT diharapkan dapat meningkatkan penguasaan informasi yang dibutuhkanj mahasiswa untuk dapat mewujudkan mutu pelayanan yang berkualitas.

\section{DAFTAR PUSTAKA}

Barkley, Bruce T and James H Saylor. (1999). Customer Driven Project Management, A New Paradigm in Total Quality Implementation Singapore.

Djumara, Noorsyamsa. (2000). Menuju Format Baru Pelayanan Umum.Bandung : LAN

Kuncoro, Sudirman dan Lukman, S.. (1999). "Visi, Misi, dan Manajemen Pelayanan Prima". Makalah dalam Lokakarya Strategi Pengembangan Pelayanan^ ${ }^{\wedge}$ Umum di Lingkungan Pemerintah Daerah, Cisarua, Bogor.

Kuncoro. Mudrajad. (2003). Metode Riset untuk Bisnis \& Ekonomi.Jakarta : Erlangga.

Tjiptono, Fandy. (1996). Manajemen Jasa.Yogyakarta : Andi.

Tjiptono, Fandy. (2000). Prinsip- Prinsip Total 
Jurnal Teknologi Pendidikan, Vol. 8 No. 2 Oktober 2015, p-ISSN; 1979-6692, e-ISSN: 2407-7437

Quality Service.Yogyakarta: Andi.

-----, (2009). Portopolio UPBJJ-UT Medan

-----, (2009). Data UPBJJ-UT Meda

-----, (2009). Panduan Penelitian Universitas

Terbuka 